\title{
Economic Efficiency of Cocoa Production in Gashaka Local Government Area, Taraba State, Nigeria
}

\author{
Taphee, B. G. ${ }^{*}$ \\ Musa, Y. H. * \\ Vosanka, I. P.* \\ *Department of Agricultural Extension and Management, Taraba State College of Agricultural Jalingo, Nigeria \\ Email: tapheegaius@gmail.com
}

\section{Doi:10.5901/mjss.2015.v6n1s1p570}

\begin{abstract}
The study was carried out to analyze the Economic Efficiency of Cocoa Production in Gashaka Local Government Area of Taraba State, Nigeria. Data for the study were collected from 80 respondents in 2012 using multi-stage sampling techniques and were analyzed using budgeting technique and profit function. The gross income per hectare was estimated to be $\mathrm{N} 53$, 250.00 while the total production cost per hectare was estimated to be $\mathrm{A116}, 470.00$, giving a gross margin per hectare of $\mathrm{A} 64$, 005.00. The net farm income was estimated to be $\mathrm{A35}$, 780.00. Purchasing costs accounted for $72.9 \%$ of the total production cost with an average cost of $\mathrm{A} 851 / \mathrm{kg}$. The Rate of Returns on Investment (RRI) was N0.75. Profit function result revealed that, labour cost and herbicide have negative relationship with the estimated profit, while cost of cocoa seed and fertilizer were found to be inversely related to profit. Major production constraints associated with cocoa production identified were inadequate support on research (20\%), inadequate farm tools (19\%) inadequate credit (17\%) and lack of storage facilities (16\%). The study recommended among others that strengthening of extension services and subsidization of farm inputs could improve farmers' profit margin in cocoa production.
\end{abstract}

Keyword: Economic Efficiency, Cocoa Production, Gashaka and constraints

\section{Introduction}

Cocoa Theobrorna cacao is an important cash crop which is believed to have originated from several localities in the area between the Andes and the upper reaches of the Amazon in South America (Julius, 2007). In the 19th century, cocoa production began to expand beyond its native base in Amazonia and Meso-America, spurred by an increased demand for chocolate as an item of mass consumption. Cote d'ivoire which was placed third in Africa with 143.000 tones behind Nigeria's 196,000 tons in 1970 is now the largest producer in the world with 1.3 million tones accounting for about $40 \%$ of the total world's production while Nigeria is currently the fourth largest producer after Cote d'ivoire, Ghana and Indonesia (International Cocoa Organization [ICCO], 2003). The dramatic growth of cocoa production in Cote d'ivoire is very interesting in that, Nigeria supplied the improved Amazon hybrid seed to Cote d'ivoire in 1965 for commercial planting to replace Amelonado variety hitherto grown (Opeke, 2003). There are over 500,000, cocoa farmers engaged in cocoa production in Nigeria, producing more than 200,000 tons of cocoa per year from over 600,000 hectares of land. Over $50 \%$ of this quantity is produced in Ondo State alone with substantial quantities produced in Oyo, Ogun and Osun States.

Most cocoa farmers in Nigeria were established over 40 years ago. Averagely, each farmer has a total of about 1.6 hectares with distribution between 0.5-20 hectares, scattered in 2-7 different locations. These farmers either own their farms by establishing the farms themselves or by inheritance from their parents. Recently, more educated people across different sectors have gone into cocoa production (Cocoa Research Institute of Nigeria [CRIN], 2000). Presently, fourteen out of the 36 states in Nigeria produce cocoa and they are grouped into three categories according to their level of production. The groups are: high producing States (Ondo, Cross River and Osun). Medium producer states (Edo, Ogun, Oyo, Ekiti, Abia, Delta and Akwa-Ibom) as well as low production states (Taraba and Adamawa). Despite the fluctuations in production, Western Nigeria remains the predominant cocoa zone, accounting for about $94 \%$ of Nigeria's total output (Olayeni in Hamzat et al., 2004; Ojo, 2003). Within western Nigeria itself, most of the crop is produced in a small contiguous area, generally referred to as the cocoa belt (Ojo, 2003).

The tree crop sub-sector of which cocoa is a major component is very important in African agriculture and 
contributes significantly to the income of farmers. It plays a critical role in sustaining biodiversity, under sound management of natural resources and provides additional pathways for the diversification and intensification of food crop systems. The relevance of cocoa to most developing economies cannot be overstressed as cocoa is produced by more than 50 developing countries across Asia, Africa and Latin America. All of these countries are in tropical and semi-tropical areas. Cocoa is a high value cash crop among farmers in the major producing areas in Nigeria. In total, more than 20 million people depend directly on cocoa for their livelihood. Approximately, $90 \%$ of the productions are exported in the form of beans or semi-manufactured cocoa products. Cocoa was among Nigeria's leading source of foreign exchange before the oil boom, and until now it is still Nigeria's largest agricultural foreign trade commodity and has helped to boost the economy of the major producing states in Nigeria. In recent years, the production of this important cash crop for export has declined in the country owing to a number of factors. The decline in production could be attributed to the following causes; advent of the petroleum sector which led to the neglect of agriculture; policies and activities of the Nigerian Cocoa Marketing Board (NCMB) of 1978-1986; non availability and high cost of cocoa production input; activities of middlemen; over- aged and low yielding trees, non-remunerative prices; non-availability of farm labour; old agronomic practices, poor nutrient status of cultivated land; and lack of credit to cocoa farmers. Other factors are the problem of poor control of pests and diseases, use of poor planting materials and poor handling of post harvest processes and inefficient agricultural extension services (Oluyole and Usman, 2006 and FGN, 2007). Also, it was revealed that the country's average production level of 239,000 metric tons recorded between 1970 and 1974 was far above the production level of 150,200 metric tons between 1999 and 2009 probably as a result of abandonment of cocoa farms. It was also observed that famers in Gashaka LGA of Taraba State, Nigeria are engaged in commercial production of cocoa. This could be because of the economic gain for its production. In the same vein farmers in the study area do not know the importance of record keeping therefore do not take into consideration the costs and returns associated with cocoa production. This neglected attitude attributed to their inability to ascertain the profitability status of their production. This study is therefore designed to:

i. describe the socio-economic characteristics of cocoa farmers in Gashaka Local Government area.,

ii. estimate the costs and returns associated with cocoa production in the study area.,

iii. determine the profit-cost relationship of cocoa production.

iv. Identify constraints militating against cocoa production in the study area.

\section{Methodology}

The study was conducted in Gashaka Local Government Area of Taraba State, Nigeria. Gashaka local government area is located roughly between latitude $30^{\circ}-20^{\prime}$ and $6^{\circ} .28^{\prime}$ North and longitudes 70.9 and $9^{\circ} .44^{\prime}$ East. It is bounded by Sardauna LGA and the Republic of Cameroon, on the East by Tongo LGA of Adamawa State, it also shares boundary on the west by Kurmi LGA, and on the North by Bali LGA. According to 2006 census figure Gashaka LGA has the population of 87,781 people. The area falls within the tropical forest Zone with thick vegetation cover, tall grasses and trees. The major rivers are: River Gashaka, Moyo Kam and Mayojim. Gashaka has a tropical climate marked by dry and rainy season. The rainy season commences early April to October while the dry season commences from October to March. The average rain fall in the area is approximately $1350 \mathrm{~mm}$. The following crops are cultivated in the area: Maize, Sorghum, Rice, Yam, Cocoa and land for grazing animal, fresh water for fishing, wildlife and forestry.

Purposive and multi-stage random sampling techniques were adopted to select respondents for the study. Five (5) out of the ten (10) wards of the study area were purposively selected. Seventeen (17) villages were considered proportional to the size of the wards as first stage. A list consisting of all the names of cocoa farmers in each of the villages were obtained and numbered, this form the second stage of the sampling process. At the final stage, a total of 110 farmers were randomly chosen for the study in a ratio proportional to the size of their population in each village. Descriptive statistic, gross margin and profit function were used as tools of analyses for the study.

The gross margin is given by the formula in equation (1)

$\mathrm{GM}=\mathrm{GFI}-\mathrm{TVC}$

Where:

$\mathrm{GM}=$ Gross Margin

$\mathrm{GFI}=$ Gross Farm Income

TVC $=$ Total Variable Cost.

Net Farm Income was calculated by the formula in equation (2)

$\mathrm{NFI}=\mathrm{GM}-\mathrm{TFC}$

(2)

Where: 
NFF = Net Farm Income

TFC $=$ Total Fixed Cost.

The rate of return on investment (ROI) is computed by equation (3) ie;

R. O. $I=\frac{N F I}{T C}$

Where:

R.O.I = Return On Investment

\section{Production Function Analysis}

The profit function relates maximized profit to the prices of product(s) and input(s), (Sankhayan, 1988 as cited by Musa, 2011). The function was used to determine the influence of the production cost on the profit from cocoa enterprise.

The generalized profit function is given as:

$\Pi=\operatorname{Pyf}(X i,-\cdots, X n, Z)-\sum$ PiXi

Where:

$\Pi=\operatorname{Profit}(\mathrm{A})$

Py $=$ Unit price of output ( $(\mathrm{N})$

PiXi $=$ Cost of variable input $(\#)$

$\mathrm{Pi}=$ Unit price of the ith variable input

$Z=$ fixed input

$X i=$ variable inputs.

The revenue equation is given as:

$\mathrm{TR}=\mathrm{PyY}$

The cost equation is given as:

$\mathrm{TC}=\mathrm{P} 1 \times 1+\mathrm{P} 2 \times 2+\mathrm{P} 3 \times 3+\mathrm{P} 4 \times 4+\mathrm{P} 5 \times 5+\mathrm{P} 6 \times 6$

The specified profit function model is stated as follows:

$\Sigma=\mathrm{PyY}-[\mathrm{P} 1 \times 1+\mathrm{P} 2 \times 2+\mathrm{P} 3 \times 3+\mathrm{P} 4 \times 4+\mathrm{P} 5 \times 5+\mathrm{P} 6 \times 6]$

Where:

$\Pi=$ Profit (\#/ha)

PyY = Value of cocoa beans ( $\mathrm{A} / \mathrm{ha})$

$\mathrm{P} 1 \times 1$ Cost of cocoa seeds. (A/ha)

P2 $\times 2=$ Cost of labour used (A/ha)

$\mathrm{P} 3 \times 3=$ Cost of herbicide used (A/ha)

$\mathrm{P} 4 \times 4=$ Cost of transportation ( $\mathrm{N})$

P5 $\times 5=$ Cost of storage $(\#)$

P6 $66=$ Fixed capital assets (A)

\section{Results and Discussion}

\subsection{Socio-economic characteristics of respondents $(n=80)$}

The socio-economic characteristics of the cocoa farmers' showed that $87.5 \%$ are males, while $12.5 \%$ are females. Also, $75 \%$ fell within the age of $31-40$ years, $36.25 \%$ are within the range of $21-30,12-50 \%$ are within the range of $4 \mid-50$ while only $2.50 \%$ are within the range of 51 years and above. The result agreed with that of FAO (1995). Marital status of the respondents indicated that $61.25 \%$ are married, $18.75 \%$ are single, and $8.75 \%$ are widows while $11.25 \%$ are divorced. This means that majority of the cocoa producers are married. This agrees with the findings of Fabiyi et al., (2007) in Gombe State. The level of education result indicated that $36 \%$ attended secondary school. About $21.25 \%$ had non-formal education, $25 \%$ attended primary school education and only $17.5 \%$ had tertiary education. These showed the farmers are literate to keep farm record that will help them to estimate their cost and returns of cocoa production. The result also revealed that farming (87.5\%) is the major occupation in the study area, $6.25 \%$ engaged in other businesses such as fishing and trading. 
Table 1: Socio- Economic Characteristics of Cocoa Farmers $(n=80)$

\begin{tabular}{|c|c|c|}
\hline Variable & Frequency & Percentage (\%) \\
\hline \multicolumn{3}{|l|}{ Sex } \\
\hline Male & 70 & 87.5 \\
\hline Female & 10 & 12.5 \\
\hline \multicolumn{3}{|l|}{ Age (years) } \\
\hline $20-30$ & 29 & 36.25 \\
\hline $31-40$ & 39 & 48.75 \\
\hline $41-50$ & 10 & 12.50 \\
\hline 51-above & 02 & 2.50 \\
\hline \multicolumn{3}{|l|}{ Marital Status } \\
\hline Married & 49 & 61.25 \\
\hline Single & 15 & 18.75 \\
\hline Widowed & 09 & 11.25 \\
\hline Divorced & 07 & 8.75 \\
\hline \multicolumn{3}{|l|}{ Educational background } \\
\hline Non-formal education & 17 & 21.25 \\
\hline Primary school education & 20 & 25.00 \\
\hline Secondary school education & 29 & 36.25 \\
\hline Tertiary education & 14 & 17.50 \\
\hline Occupation & & 87.5 \\
\hline Farming & 70 & \\
\hline Fishing & 04 & 3.75 \\
\hline Trading & 05 & 6.25 \\
\hline Others & 01 & 1.25 \\
\hline \multicolumn{3}{|l|}{ Farming experience(years) } \\
\hline $1-10$ & 22 & 40.00 \\
\hline $11-20$ & 35 & 43.75 \\
\hline $21-30$ & 11 & 13.75 \\
\hline 31-above & 02 & 2.50 \\
\hline Farm size ( hectares) & 20 & 25.00 \\
\hline $0-2$ & 45 & 56.25 \\
\hline 3-4 & 15 & 18.75 \\
\hline 5-above & & \\
\hline
\end{tabular}

Source: Field Survey, 2012.

Farming experience shows that $43.75 \%$ of the respondents had farming experience of $11-20$ years, $40.5 \%$ had $1-10$ years experience and about $13.75 \%$ had farming experience of 21-30 years, and about $2.50 \%$ had farming experience between 31 years and above. This shows that most of the farmers are experienced farmers in cocoa production. Majority of the respondents representing $75 \%$ had farm size of 3 hectares and above, therefore referred to as small scale farmers.

\section{Cost and Return Analysis}

The costs and returns analysis of cocoa production per hectare as shown in Table 2 indicated that average variable costs were estimated to be $\mathbf{A} 88,245.00$ while the fixed cost amounted to $\mathrm{A} 28,225.00$ per hectare. The returns in naira in terms of gross income, gross margin, net income and return per each naira invested per hectare were estimated at $\mathrm{A}$ $153,250.00, \$ 64,005.00, \$ 35,780.00$ and $\$ 0.7565$ respectively. This result concurs with the finding of Folayan et al., (2006); Gotsch and Burger (2001). 
Table 2: Average Costs and Returns Analysis of Cocoa Production

\begin{tabular}{lc}
\hline Cost/returns & Average values/mount (N) \\
\hline Variable costs & \\
Purchasing costs & $64,345.00$ \\
Transportation costs & $2,450.00$ \\
Storage/handing cost & $3,150.00$ \\
Labour costs & $13,200.00$ \\
Contingency costs & $5,100.00$ \\
Total variable & $\mathbf{8 8 , 2 4 5 . 0 0}$ \\
Fixed costs & \\
Land lease costs & $26,000.00$ \\
Utilities costs & $2,225.00$ \\
Total fixed costs & $\mathbf{2 8 , 2 2 5 . 0 0}$ \\
Total Cost (VC+FC) & $116,470.00$ \\
Returns & \\
Gross income & $153,250.00$ \\
Gross margin & $64,005.00$ \\
Net income & 35,780 \\
Per naira investment & $\mathbf{0 . 7 5 6 5}$ \\
\hline
\end{tabular}

Source: Field Survey, 2012.

\section{Estimated Production Function for Cocoa}

Profit function was used to determine the influence of costs associated with cocoa production on the profit realized. This involved the use of four functional forms (Linear, Exponential, Cob-Douglas and Semi-log) for the analysis. The semi-log function had the best fit and was selected as the lead equation. The selection was based on the magnitude of coefficient of multiple determinations $\left(R^{2}\right)$, the aprori expectation and the statistical significance of the estimated regression coefficients. The summary of the estimated relationship is expressed in Table 3. The result indicates that cost of cocoa seed and herbicide were inversely related to farmers profit at $5 \%$ level. This implies that as the costs of cocoa seeds and herbicides decrease, profit increases. This scenario is attributed to the relatively high cost of cocoa seeds during planting periods as well as high cost of herbicides due to scarcity.

However, the coefficient of labour was found to be positive and significant at $1 \%$ level, implying that as labour cost increases, so also the profit. This increase in labour cost in cocoa production results from seasonal scarcity and over dependence on much hired labour during farm operations. This is obvious, because most cocoa operations such as land clearing, weeding and harvesting are done manually and these demand much in terms of labour requirements.

Table 3: Semi-Log Profit Function Result.

\begin{tabular}{ccc}
\hline Variables & Coefficient & t-value \\
\hline Seed cost $\left(X_{1}\right)$ & -3913.892 & \\
Labour Cost $\left(X_{2}\right)$ & 44642.954 & $-2.0861^{* *}$ \\
Herbicide cost $\left(X_{3}\right)$ & -3519.094 & $10.1955^{*}$ \\
Transport cost $\left(X_{4}\right)$ & 221.930 & $-2.24622^{* *}$ \\
Storage Cost $\left(X_{5}\right)$ & -101.692 & 0.370 \\
Fixed cost $\left(X_{6}\right)$ & 2500.672 & -1.192 \\
Constant & -137517.178 & -1.440 \\
$R^{2}$ & 0.561 & \\
F-ratio & $20.488 *$ & \\
\hline
\end{tabular}

Significant at $1 \%\left(^{*}\right)$ and $5 \%(* *)$ levels respectively.

Source: Computer print out.

\section{Constraints Encountered in Cocoa Production}

Inadequate support on research was found to be the most important problem (20\%) of cocoa production in the study 
area; this will affect the adoption of innovations to slow pace. Also, inadequate farm inputs representing $19 \%$ of the respondents was found as the farmers' most important constraint in cocoa production. These inputs are farm implements and some vital farm requirements (agro-chemicals, fertilizers, seed etc). This would be attributed to government inabilities in supplying these essential inputs for the support of agricultural activities. Lack of modem storage facilities also constituted a constraint (16\%) for the production of cocoa in Gashaka LGA. This could lead to an increased attack of insect pest on cocoa produce and subsequently a decline in cocoa returns of the farmers in the study area. Lack of improved varieties (11\%) also posed a problem in the area. This could not allow for commercial production of cocoa to meet the demand of international market. Hence, subsistence level of production will be in practice. Other problems that were identified are high costs of agro-chemical (9\%) and lack of government assistance (8\%). These also may contribute to impediment of bumper harvest in the cocoa producing area(s).

Table 4: Constraints of Cocoa Production

\begin{tabular}{lcc}
\hline Major constraints & Frequency $^{*}$ & Percentage (\%) \\
\hline Inadequate support on research & 74 & 20 \\
Inadequate farm input & 73 & 19 \\
Lack of adequate credit & 62 & 17 \\
Lack of storage facilities & 58 & 16 \\
Lack of improved varieties & 44 & 11 \\
High cost of agro-chemical & 34 & 9 \\
Lack of government assistance & 30 & 8 \\
\hline
\end{tabular}

*Multiple responses.

Source: Field Survey, 2012.

\section{Conclusion and Recommendations}

From the findings of the study, it can be concluded that cocoa production in the study area is a profitable business. Marketing for cocoa is thus different from other food crops as it is pruned to price fluctuations. Costs of cocoa seed and herbicides were inversely related to farmers' profit at $5 \%$ probability level while the coefficient of labour was positively related and statistically significant at $1 \%$ level of probability indicating that, as labour cost increases the profit increases.

The following recommendations are therefore proffered so as to increase the farmers' output in the study area.

1. Extension agents should as a matter of concern mount serious campaign to create awareness to farmers, most especially cocoa farmers because it is a viable cash crop.

2. Since the marketing of coca is left to market forces, government should as a matter of urgency set up an agency that will determine the market price of the commodity based on average cost of production every cropping season.

3. Government or NGOs should assist the farmers by providing them with subsidized inputs such as fertilizer and other agrochemicals.

4. Pest and disease resistant and high yielding seed varieties of cocoa should be introduced or made available to cocoa farmers in order to minimize costs.

\section{References}

Adegeye, A.J. (2000). Nigerian Agriculture Reaping where we do not sow. Tropical issues in Nigerian Agriculture: Desirable and workable Agricultural policies for Nigeria in the first Decade of the 218t century Department of Agricultural Economics, University of Ibadan, Ibadan Nigeria: 1-20.

Adeogun, S.O (2008). Adoption of cocoa rehabilitation techniques among cocoa farmers in selected States of Nigeria. Ph.D Thesis Department of Agricultural Extension and Rural Development, University of Ibadan, Nigeria: 1-191.

Adeogun, S.O. (2008a). Cocoa rehabilitation in Nigeria Global Research on cocoa. Issue 14, December, 2008: 2-5.

Adetunji, M.O., Olamyi, O.A. and Raufu, M.O, (2007). "Assessment of Benefits Derived by cocoa farmers from cocoa development unit Activities of Oyo State" Journal of Human Ecology 22 (3): 211-214.

Alkin, M.C. (1990). Debates on Evaluation. Newbury Park: Sage Publications: 25-30.

Amos, T.T. (2007). Analysis of productivity and technical efficiency of small Holder cocoa farmers in Nigeria. Journal of social science, 15 (2): 127-133.

Ayoola, B.F, Badaru, K. and Aikpokpodion, P.A (2000), Development of the Nigerian cocoa industry in Nigeria. Agricultural Journal. Vol. 
$31 ; 18-23$.

Babalola, A. (2009). Imperatives of agricultural development to Nigeria's industrialization agenda. Guardian Newspaper: 35.

Baras, C. (2006) poultry as a tool in poverty eradication and promotion of gender: 67-73.

Cocoa Research Institute of Nigeria (CRIN), (2000) Information Booklets of Cocoa Research Institute of Nigeria. Ibadan: CRIN press; 1 30.

Cocoa Research Institute of Nigeria (CRIN), (2006), Information Booklets of Cocoa Research institute of Nigeria. Ibadan: CR1N Press: 5-10.

Daramola A.G., Fuwape J.A, Ofuya T.I, Okunlola J.O, Ajibefun I.A., Okuku I.E, Oke D.O, Aladesaiye E., Badaru K.B, and Olaiya A.O. (2003). Evaluation of Sustainable Options for Rehabilitation for Small Holder Nigerian Farmers. Sustainable and Competitive Cocoa System in Africa.

Ekong, E .E. (2003). Rural Sociology: An Introduction and Analysis of Rural Nigeria. Uyo: Dove Educational Publishers: $256-288$.

Fabiyi, E.F., Danladi, B.B., Akande, K.E, and Mohmod, Y. (2007). "Role of Women in Agricultural Development and their constraints: A case study Biliri local Government Area of Gombe State Nigeria". Pakistan Journal of Nutrition 6 (6): 676- 680.

FAO (1995). Women, Agriculture and Rural Development in the Near East: finding of an FAO study, Rome Italy.

Federal Government of Nigeria [FGN] (2007). Sustainable cocoa economy- the Nigerian experience. Being the text of the paper presented as the Nigerian country paper at the 2 African cocoa summit held on 5th September 2007 in Aloro Ghana: 1-9.

Federal Republic of Nigeria [FRN], (2006). Nigeria national report on international conference on ograrian reform and rural development held at porto Alore 7-10 march: 1-23.

Folayan, J.A, G.A, Daramola and A.E, Oguntade. (2006). Structure and performance Evaluation of cocoa marketing Institutions in SouthWestern Nigeria: An Economic Analysis. Journal of food, Agriculture and Environment. 4 (2): 125 - 128.

Gotch, N. and Burger K, Dynamic Supply response and welfare effects of technological change on perennial crops: The case of cocoa in Malaysia, American Journal of Agricultural Economics, (2001). 83 (2): 272-285.

Gray, A. (2001). The world cocoa market outlook. Ghana conference Paper, May, 2000. LMC international Ltd, Ghana.

ICCO, (2003) ICOO Quarterly Bulletin of cocoa statistics Retrieved from http://www.ICCo.org.

International Cocoa Organization's (ICCO) (1998). International cocoa Organization's Quarterly Statistics. Retrieved from. http://www.icco.org.

Julius, O. (2007). The roles of agriculture, Petroleum and energy in combating poverty and promoting economic development. An address Presented at the institute of chartered or Nigeria (ICEN) mandatory advancement continuous.

Musa,Y.H; Vosanka, I.P; Shehu, J.F. and Maurice, D.C. (2011). Analysis of the Profitability of Yam Production in Zing Local Government Area of Taraba State, Nigeria. International Journal of Agriculture. Vol. 3, Number 5, 2011.

Nkang, N. M., Abange, S.O., Akpan, O.E. and Offem, K.J. (2006) Cointegration and error correction modeling of agricultural export trade in Nigeria: the case of cocoa, Journal of Agriculture and social sciences, (Accepted).

Nweke, F.I. and A.A Enete. (1999). Gender Surprises in food production, processing No. 19, cocoa IITA, Ibadan, Nigeria.

Oduwole, O.O. (2004). Adoption of Improved Agronomic Practices by Cocoa Farmers in Nigeria: A Multivariate Tobit Analysis. Ph.D. Thesis (Unpublished), Akure: Federal University of Technology, Nigeria.

Oluyole K.A. and Usman J.M. (2006). Assessment of Economic Activities of Cocoa Licensed Buying Agents (LBAs) in Odeda Local Government Area of Ogun state, Nigeria. Akoka Journal of Technology and Science Education, 3(1): 130-140.

Sankhayan, P. L. (1988). Introduction to Agricultural Production Economics. Prentice-Hall of India Private Limited. New Delhi. P.84. 